\title{
Kekuatan Batas Lambung Kapal dalam Menahan Momen Lentur Vertikal
}

\author{
Azhar Aras Mubarak ${ }^{1 *}$, Ganding Sitepu ${ }^{1}$, Muhammad Zubair Muis Alie ${ }^{1}$ \\ ${ }^{1}$ Departemen Teknik Perkapalan, Fakultas Teknik, Universitas Hasanuddin \\ Jl. Poros Malino Km. 6, Bontomarannu, Kabupaten Gowa, Sulawesi Selatan, 92171 \\ *Email: arasmubarak28@gmail.com
}

DOI: 10.25042/jpe.052018.10

\begin{abstract}
Abstrak
Dalam perjalanannya, kapal akan terus-menerus mendapat beban struktur yang diakibatkan oleh beban eksternal dari gelombang dan beban internal dari muatan kapal dan struktur itu sendiri yang kemudian mencapai kekuatan batas (ultimate strength) pada struktur tersebut. Penelitian ini bertujuan untuk mengetahui kekuatan batas lambung kapal akibat momen lentur vertikal sehingga struktur kapal dapat dijamin keamanannya. Analisa dilakukan dengan menggunakan metode elemen hingga (FEM) dengan memodelkan struktur penampang kapal tanker yang dimodifikasi berdasarkan dari bentuk box girder sehingga didapatkan model yang lebih sederhana. Perhitungan ini dilakukan dengan menggunakan software ANSYS 17. Perhitungan struktur kapal disimulasi berdasarkan dua model yang ada yakni model box girder dan model tanker yang telah dimodifikasi. Pada model box girder, kekuatan batas diperoleh 6.311 x $10^{8} \mathrm{Nmm}$ pada kondisi hogging dan -6.311 x $10^{8}$ $\mathrm{Nmm}$ pada kondisi sagging. Sedangkan pada model tanker, kekuatan batas yang diperoleh adalah $-8.99 \times 10^{12} \mathrm{Nmm}$ pada kondisi sagging dan 10,277 x $10^{12} \mathrm{Nmm}$ pada kondisi hogging.
\end{abstract}

\begin{abstract}
Ultimate Strength of Hull Structure due to Vertical Bending Moment. On the life, the ship will constantly get the structural load caused by the external load of the internal waves and loads of the ship's load and the structure itself which then reaches the ultimate strength of the structure. This study aims to determine the strength of the boundary of the hull due to the vertical bending moment so that the ship structure can be guaranteed security. The analysis was done by using finite element method (FEM) by modeling the structure of the tanker section modified based on the shape of the girder box so that a simpler model is obtained. This calculation is done by using ANSYS 17 software. The calculation of vessel structure is simulated based on two existing models namely girder box model and modified tanker model. In the girder box model, ultimate strength is obtained at $6,311 \times 10^{8} \mathrm{Nmm}$ for hogging conditions and $-6.311 \times 10^{8} \mathrm{Nmm}$ for sagging conditions. While on the tanker model, the ultimate strength obtained is $-8.99 \times 10^{12} \mathrm{Nmm}$ for sagging conditions and $10,277 \times 10^{12}$ Nmm for hogging conditions.
\end{abstract}

Kata Kunci: Metode Elemen Hingga, Kondisi Hogging-Sagging, Ultimate Strength

\section{Pendahuluan}

Pada dasarnya kapal adalah suatu alat transportasi yang beroperasi dilaut dengan sistem yang sangat kompleks. Kapal didesain sedimikian rupa sehingga mampu menjamin keselamatan dalam pelayaran. Dalam operasinya, kapal sering mengalami kegagalan struktur baik disebabkan dari faktor luar seperti cuaca, lingkungan dan sebagainya, maupun dari struktur kapal itu sendiri seperti deformasi awal, korosi, tekanan sisa dan lain-lain serta kegagalan struktur yang disebabkan oleh human error (kesalahan manusia).
Kemudian hal yang sangat penting dalam analisis suatu struktur kapal adalah melakukan analisis atas kemampuan suatu struktur tersebut untuk memenuhi tujuan desain yang telah ditetapkan, termasuk disini adalah bahwa struktur tidak akan mengalami kegagalan dalam pengoperasian kapal nantinya. Karena konsep perancangan struktur yang baik adalah struktur tersebut harus memberikan keamanan terhadap kemungkinan kegagalan yang terjadi selama masa operasi dari struktur tersebut.

Struktur kapal pada arah longitudinal umumnya memiliki komponen-komponen yang 
saling berhubungan dan memperkuat satu sama lainnya yang ditemukan pada konstruksi sisi, konstruksi geladak dan konstruksi bottom. Konstruksi tersebut diperkuat oleh pelat kapal, senta lambung, stiffener, balok geladak, center girder, side girder, penumpu geladak, sheer strake, dan lain-lain. Semua konstruksi sisi, bottom, dan geladak mendapat bending, momen di arah vertikal, momen horizontal serta puntiran (torsi). Semua struktur tersebut memiliki batas kekuatan, sehingga ketika struktur tersebut terus menerus mendapat beban baik itu beban eksternal dari gelombang dan beban internal dari muatan kapal dan struktur itu sendiri maka akan mencapai kekuatan batas (Ultimate Strength) pada struktur tersebut.

Sistem kerangka/konstruksi kapal (framing system) dibedakan dalam dua jenis utama; yaitu sistem kerangka melintang (transverse framing system) dan sistem membujur atau memanjang (longitudinal framing system). Dari kedua sistem utama ini maka dikenal pula sistem kombinasi (combination/mixed framing system) yang merupakan gabungan antara keduanya [1].

Pemilihan jenis sistem untuk suatu kapal sangat ditentukan oleh ukuran kapal dan jenis/fungsi kapal juga menjadi dasar pertimbangan [1], dijelaskan:

\section{a. Sistem Konstruksi Melintang}

Dalam sistem ini gading-gading (frame) dipasang vertikal (mengikuti bentuk body plan) dengan jarak antara (spacing), ke arah memanjang kapal, satu sama lain yang rapat (sekitar antara $500 \mathrm{~mm}-1000 \mathrm{~mm}$, tergangung panjang kapal). Pada geladak, baik geladak kekuatan maupun geladak-geladak lainnya, dipasang balok-balok geladak (deck beam) dengan jarak antara yang sama seperti jarak antara gading-gading. Ujung masing-masing balok geladak ditumpu oleh gading-gading yang terletak pada vertikal yang sama. Pada alas dipasang wrang dengan jarak yang sama pula dengan jarak antara gadinggading sedemikian rupa sehingga masing-masing wrang, gading-gading dan balok geladak membentuk sebuah rangkaian yang saling berhubungan dan terletak pada satu bidang vertikal sesuai penampang melintang kapal pada tempat yang bersangkutan. b. Sistem Konstruksi Membujur

Dalam sistem ini gading-gading utama tidak dipasang vertikal, tetapi dipasang membujur pada sisi kapal dengan jarak antara, diukur ke arah vertikal, sekitar $700 \mathrm{~mm}-1000 \mathrm{~mm}$. gading-gading ini (pada sisi) dinamakan pembujur sisi (side longitudinal). Pada setiap jarak tertentu (sekitar 3$5 \mathrm{~m}$ ) dipasang gading-gading besar, sebagaimana gading-gading besar pada sistem melintang, yang disebut pelintang sisi (side transverse). Pada alas, dan alas dalam, juga dipasang pembujur-pembujur seperti pembujur-pembujur sisi tersebut di atas dengan jarak antara yang sama pula seperti jarak antara pembujur-pembujur sisi. Pembujurpembujur ini dinamakan pembujur-pembujur alas (bottom longitudinal) dan, pada alas dalam, pembujur alas dalam (inner bottom longitudinal). Pada alas juga dipasang wrang-wrang, dan dihubungkan pada pelintang-pelintang sisi. Tetapi umumnya tidak pada tiap pelintang sisi; yaitu setiap dua, atau lebih, pelintang sisi. Wrangwrang pda sistem membujur juga dinamakan pelintang alas (bottom transverse). Penumpu tengah dan penumpu samping sama halnya seperti pada sistem melintang.

\section{c. Sistem Konstruksi Kombinasi}

Sistem kombinasi ini diartikan bahwa sistem melintang dan sistem membujur dipakai bersamasama dalam badan kapal. Dalam sistem ini geladak dan alas dibuat menurut sistem membujur sedangkan sisinya menurut sistem melintang. Jadi, sisi-sisinya diperkuat dengan gading-gading melintang dengan jarak antara yang rapat seperti halnya dalam sistem melintang, sedangkan alas dan geladaknya diperkuat dengan pembujurpembujur. Dengan demikian maka dalam mengikuti peraturan klasifikasi (rules) sisi-sisi kapal tunduk pada ketentuan yang berlaku untuk sistem melintang, sedangkan alas dan geladaknya mengikuti ketentuan yang berlaku untuk sistem membujur, untuk hal-hal yang memang diperlukan secara terpisah.

Kekuatan-batas kapal $\left(\mathrm{M}_{\mathrm{U}}\right)$ harus dihitung dengan metode NLFEA atau metode buckling dan harus memenuhi kriteria seperti Persamaan di bawah ini [2]. 


$$
\gamma_{R} \leq \frac{M_{U}}{M_{t}}
$$

dimana $\mathrm{M}_{\mathrm{t}}$ adalah momen lentur-batas total vertikal dan $\gamma_{R}$ adalah faktor keamanan untuk kekuatan-batas lentur vertikal $(1,1$ untuk kondisi sagging dan 1,21 untuk kondisi hogging).

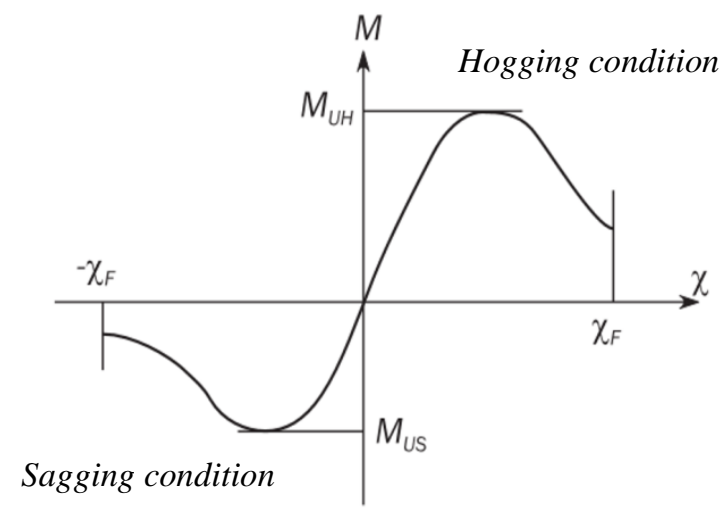

\section{Gambar 1. Grafik kekuatan momen lentur dan kelengkungan [2]}

Hubungan antara kekuatan-batas momen lentur dan kelengkungan ditunjukkan pada Gambar 1. Nilai kelengkungan yang positif menunjukkan kondisi hogging dan nilai kelengkungan yang negatif menunjukkan kondisi sagging.

Tegangan lentur maksimum $\left(\sigma_{\max }\right)$ dapat dihitung dengan menggunakan Persamaan sebagai berikut:

$$
\sigma_{\max }=\frac{M}{S}
$$

dimana $\mathrm{S}$ adalah modulus penampang.

Tegangan didefinisikan sebagai besaran gaya yang bekerja pada suatu satuan luas. Secara matematis definisi tersebut dapat ditulis sebagai berikut:

$$
\sigma=\frac{F}{A}
$$

Dimana :

$\sigma \quad=$ tegangan $\left(\mathrm{N} / \mathrm{mm}^{2}\right)$

$\mathrm{F}$ = gaya yang bekerja atau beban $(\mathrm{N})$

$A=$ luas penampang $\left(\mathrm{mm}^{2}\right)$
Pada Gambar 2, dapat dilihat bahwa suatu bidang yang dikenal suatu gaya akan terdapat dua jenis tegangan yang mempengaruhi bidang tersebut, yaitu tegangan normal dan tegangan geser. Tegangan normal adalah tegangan yang bekerja tegak lurus terhadap bidang sedangkan tegangan geser adalah tegangan yang bekerja sejajar dengan bidang [3]. Komponen-komponen tegangan bidang bekerja dalam dua arah saja (tidak pada arah sumbu $\mathrm{z}$ ) dan tegangan geser $\mathrm{xy}$ sama dengan tegangan yx.

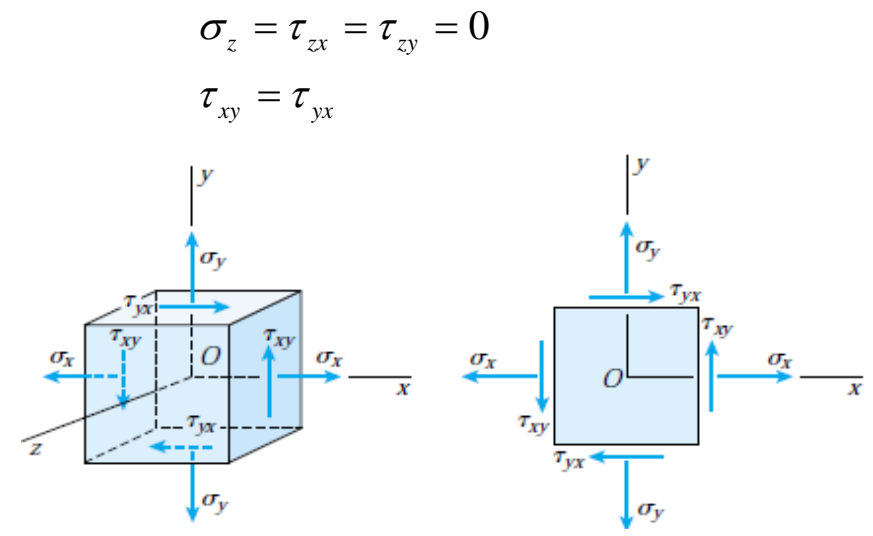

Gambar 2. Tegangan yang bekerja pada suatu bidang $x y$ [3]

Keterangan :

$$
\begin{aligned}
\sigma_{x}= & \text { tegangan normal yang bekerja pada } \\
& \text { bidang } \mathrm{x} \\
\sigma_{y}= & \text { tegangan normal yang bekerja pada } \\
& \text { bidang } \mathrm{y} \\
\tau_{x y}= & \text { tegangan geser yang bekerja pada } \\
& \text { bidang normal } \mathrm{x} \text { dalam arah } \mathrm{y}
\end{aligned}
$$

Tegangan izin adalah tegangan yang mengakibatkan suatu konstruksi mengalami lendutan yang besar dimana lendutan tersebut adalah batas sebuah konstruksi masih aman dalam mengatasi beban yang terjadi atau yang bekerja padanya. Apabila tegangan izin dari konstruksi bersangkutan lebih kecil dari tegangan maksimum yang terjadi, maka konstruksi tersebut tidak aman. Secara khusus ditentukan oleh, bahwa tegangan izin yang bekerja tidak boleh melewati [4] : 
Tegangan Ekivalen $=\frac{180}{k}\left[\mathrm{~N} / \mathrm{mm}^{2}\right]$, dengan $\mathrm{k}=$ faktor baja

Baja struktur lambung adalah baja yang mempunyai nominal nilai luluh atas minimal (yield point) $\mathrm{R}_{\mathrm{EH}} 235 \mathrm{~N} / \mathrm{mm}^{2}$ dan kekuatan tarik (tensile strenght) $\mathrm{R}_{\mathrm{m}} 400-520 \mathrm{~N} / \mathrm{mm}^{2}$.

Dengan masalah yang begitu kompleks tersebut, sangat diperlukan analisis terlebih dahulu untuk mengetahui respon struktur pada kapal sehingga, analisis kekuatan batas longitudinal lambung kapal dalam menahan momen lentur vertikal sangat penting untuk dilakukan.

\section{Metode}

Jenis penelitian ini yaitu penelitian kuantitatif dengan menggunakan metode ekperimen numerik. Kegiatan peneltian dilakukan di Laboratorium Komputer Jurusan Teknik Perkapalan Fakultas Teknik Universitas Hasanuddin, dengan pengambilan data pada penelitian sebelumnya [5].

Data yang dikumpulkan dalam penelitian ini terdiri dari data primer dan data sekunder. Dalam penelitian ini, data primer yang dikumpulkan berupa konfigurasi penampang kapal tanker yang digunakan. Data sekunder diperoleh dari tulisan seperti buku teori, peraturan-peraturan dan dokumen hasil kajian literatur yang berhubungan dengan kajian kekuatan kekuatan batas struktur kapal.

Pada tahap pertama data awal dikumpulkan berupa ukuran utama kapal dan konfigurasi penampang konstruksi kapal. Bersamaan dengan proses pengumpulan data, studi literatur dilakukan untuk mengetahui kekuatan batas struktur kapal . Studi yang dimaksud adalah studi literatur untuk mengetahui besar beban dinamis yang bekerja pada konstruksi kapal yaitu beban gelombang yang mengakibatkan kondisi sagging dan hogging. Setelah data awal dan data hasil olahan pada studi literatur didapatkan, data diolah kembali dengan menggunakan ekperimen numerik dengan menggunakan bantuan perangkat komputer dengan piranti lunak (software) yang mengadopsi metode elemen hingga pada sistem pemogramannya. Software yang akan digunakan mampu mengeluarkan nilai kekuatan batas dan tegangan yang terjadi pada struktur setelah diberikan beban ekternal.

Pada tahap ini kapal akan dimodelkan kedalam bentuk gambar tiga dimensi pada komputer sesuai dengan data awal yang didapatkan. Simulasi model akan dilakukan dengan melakukan analisa kepada box girder terlebih dahulu untuk mendapatkan kekuatan batas dan dibandingkan dengan penelitian sebelumnya [6].

Grafik yang telah ditemukan mempunyai kesesuaian dengan grafik penelitian terdahulu. Kemudian dilakukan analisis kekuatan batas terhadap kapal tanker yang telah dimodifikasi. Grafik yang dihasilkan adalah perbandingan antara momen dan curvature serta grafik perbandingan momen dengan displacement. Besaran nilai kekuatan batas yang didapatkan kemudian dibandingkan dengan perhitungan rumus empiris yang dihitung berdasarkan persamaan [6] sehingga didapatkan berapa besar faktor keamanan struktur tersebut.

\section{Pembahasan}

Penelitian ini menunjukkan hasil perhitungan kekuatan didapatkan menggunakan NLFEA pada box girder dan kapal tanker pada kondisi hogging dan sagging. Untuk menganalisis kapal tanker yang menjadi objek penelitian, diawali dengan memodifikasi kapal tanker menjadi kotak sehingga menjadi lebih sederhana. Pada kondisi hogging, penampang bagian deck akan mengalami tarik dan dibagian bottom akan mengalami tekan. Sedangkan pada kondisi sagging, penampang bagian deck akan mengalami tekan dan bagian bottom akan mengalami tarik. Ini disebabkan oleh proses control moment yang dilakukan. Adanya bentuk kondisi sagging dan hogging mengakibatkan deformasi pada bagian deck dan bottom mengalami perubahan bentuk, dimana stiffener dan pelat yang terdapat pada bagian tersebut mengalami tekuk.

Analisis perbandingan kekuatan batas kapal tanker dan referensi rules yang digunakan menunjukkan bahwa struktur kapal tersebut telah memenuhi persyaratan keamanan yang dikeluarkan oleh DNV GL. Penelitian yang 
dilakukan sebelumnya [6] juga menunjukkan adanya kesesuaian grafik yang dihasilkan yaitu grafik antara momen dan curvature serta grafik antara momen dan displacement.

Hasil analisis kekuatan batas momen lentur vertikal box girder dengan metode NLFEA menggunakan software ANSYS diperoleh nilai kekuatan batas box girder ketika mengalami hogging sebesar $6.311 \times 10^{8} \mathrm{Nmm}$ dan pada saat sagging sebesar $-6.311 \times 10^{8} \mathrm{Nmm}$. Sedangkan Hasil analisis kekuatan batas momen lentur vertikal kapal tanker dengan metode NLFEA diperoleh nilai kekuatan batas kapal tanker ketika mengalami hogging sebesar 10,2 x $10^{12} \mathrm{Nmm}$ dan pada saat sagging sebesar $-8.99 \times 10^{12} \mathrm{Nmm}$. Adapun hubungan antara nilai kekuatan batas dan curvature/ kelengkungan dengan menggunakan metode NLFEA di ansys dapat dilihat pada Gambar 3.

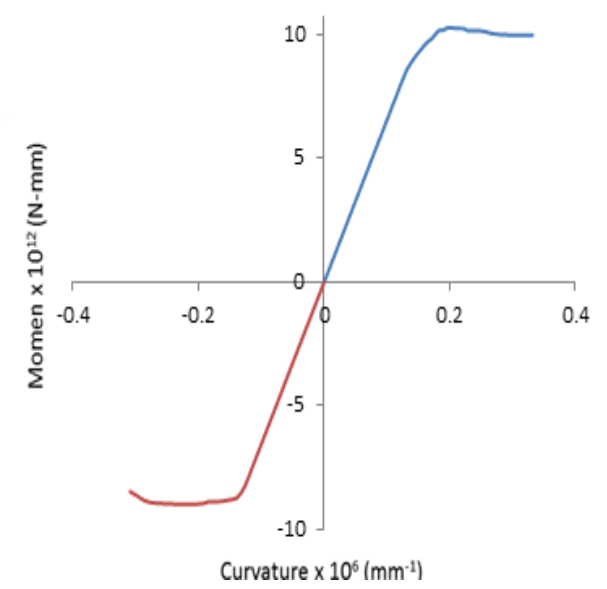

Gambar 3. Momen kelengkungan kapal tanker

Pada kondisi hogging, Gambar 3 menjelaskan tentang momen lentur-batas vertikal dari $0 \mathrm{Nmm}$ sampai $9.24 \times 10^{12} \mathrm{Nmm}$ kapal tanker dalam kondisi masih linear, selanjutnya 9,24 x $10^{12}$ $\mathrm{Nmm}$ sampai 9,95 x $10^{12} \mathrm{Nmm}$ kapal tanker sudah berada pada kondisi tidak linear. Ketika kapal tanker dengan besar momen lentur 1,02 x $10^{13} \mathrm{Nmm}$ telah mencapai momen ultimate yang membuat struktur mengalami buckling.

Pada kondisi sagging momen lentur-batas vertikal dari $0 \mathrm{Nmm}$ sampai $-8,26 \times 10^{12} \mathrm{Nmm}$ kapal tanker dalam kondisi masih linear, selanjutnya $-8,27 \times 10^{12} \mathrm{Nmm}$ sampai $-8,85 \times 10^{12}$ $\mathrm{Nmm}$ kapal tanker sudah berada pada kondisi tidak linear. Ketika kapal tanker dengan besar momen lentur $-8,98 \times 10^{12} \mathrm{Nmm}$ telah mencapai momen ultimate yang membuat struktur mengalami buckling.

Adapun grafik hubungan antara momen lentur dengan displacement yang terjadi pada struktur dapat dilihat pada Gambar 4 yang menunjukkan bahwa pada kondisi hogging, momen lentur-batas vertikal dari $0 \mathrm{Nmm}$ sampai $9.41 \times 10^{12} \mathrm{Nmm}$, displacement kapal tanker dalam kondisi masih linear, selanjutnya $9,42 \times 10^{12} \mathrm{Nmm}$ sampai 1,01 $\mathrm{x} 10^{12} \mathrm{Nmm}$ kapal tanker sudah berada pada kondisi tidak linear. Ketika kapal tanker dengan besar momen lentur $1,02 \times 10^{13} \mathrm{Nmm}$ telah mencapai momen ultimate yang membuat struktur menuju tak terhingga.

Pada kondisi sagging, momen lentur-batas vertikal dari $0 \mathrm{Nmm}$ sampai $-8,5 \times 10^{12} \mathrm{Nmm}$, displacement kapal tanker dalam kondisi masih linear, selanjutnya $-8,6 \times 10^{12} \mathrm{Nmm}$ sampai $-8,8 \times$ $10^{12} \mathrm{Nmm}$ kapal tanker sudah berada pada kondisi tidak linear. Ketika kapal tanker dengan besar momen lentur $-8,99 \times 10^{12} \mathrm{Nmm}$ telah mencapai momen ultimate yang membuat struktur menuju tak terhingga.

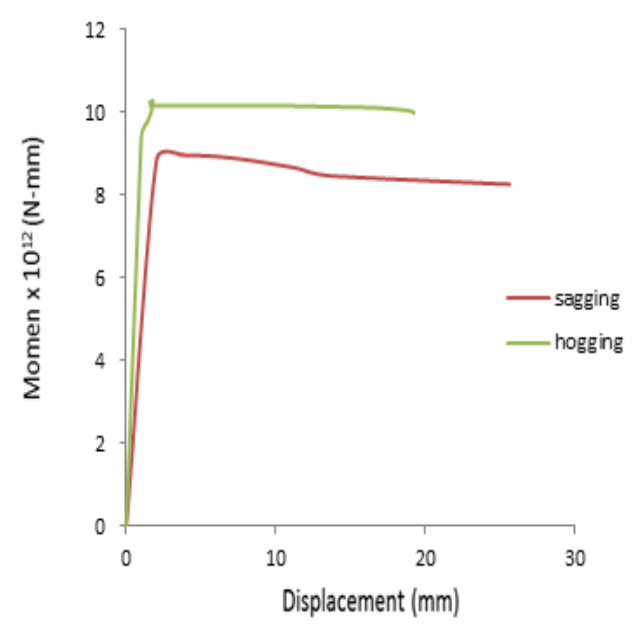

Gambar 4. Momen lentur - displacement pada kapal tanker

Tegangan kerja yang terjadi pada kapal tanker pada saat hogging adalah sebesar $-353.49 \mathrm{~N} / \mathrm{mm}^{2}$ di bottom dan $359.03 \mathrm{~N} / \mathrm{mm}^{2}$ di deck seperti pada Gambar 5. 


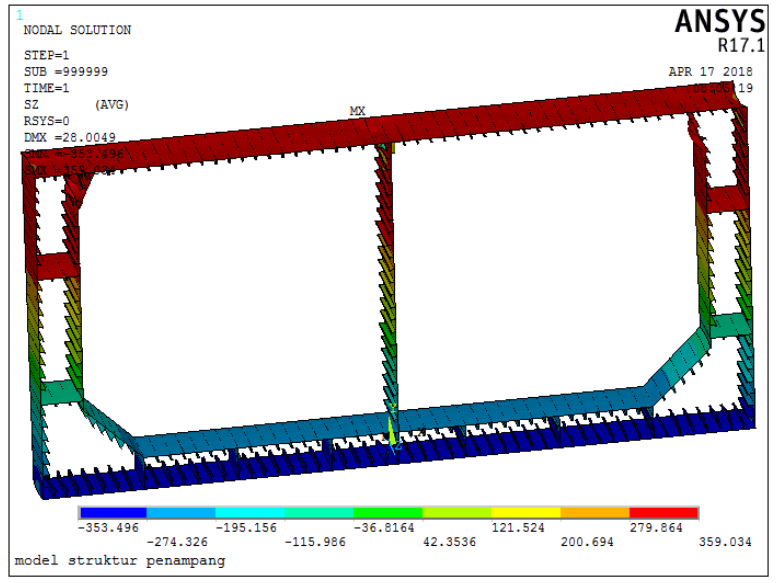

Gambar 5. Distribusi tegangan akibat kondisi hogging

Pada kondisi hogging, penampang bagian deck akan mengalami tarik dan dibagian bottom akan mengalami tekan. Sehingga besaran nilai tegangan yang terjadi akan berbeda. Ini dikarenakan proses control moment yang dilakukan. Pada Gambar 5 juga menunjukkan adanya deformasi yang terjadi pada struktur berupa terjadinya buckling terhadap beberapa bagian pada deck dan bottom.

Adapun tegangan kerja yang terjadi pada kapal tanker pada kondisi sagging adalah pada bottom sebesar $-352.337 \mathrm{~N} / \mathrm{mm}^{2}$ dan pada deck sebesar $287.72 \mathrm{~N} / \mathrm{mm}^{2}$ seperti pada Gambar 6 .

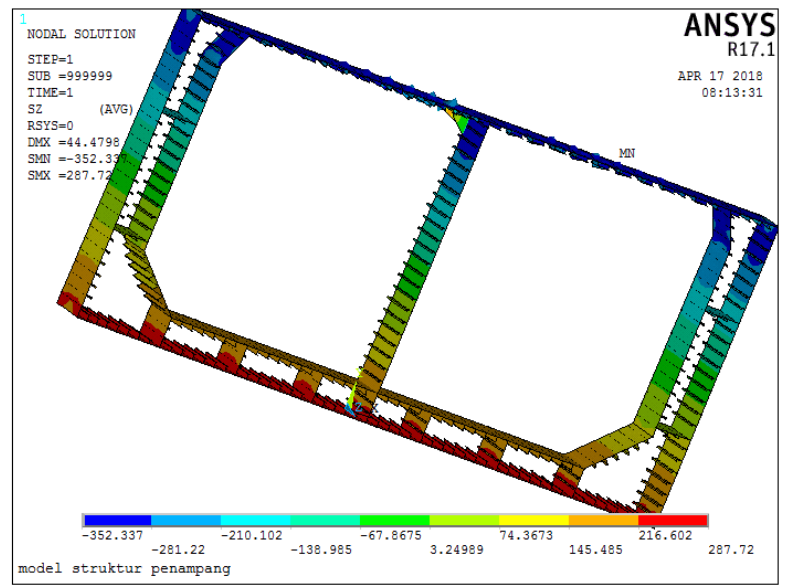

Gambar 6. Distribusi tegangan akibat kondisi sagging

Pada kondisi sagging, penampang bagian deck akan mengalami tekan dan dibagian bottom akan mengalami tarik. Sehingga besaran nilai tegangan yang terjadi akan berbeda. Ini juga disebakan oleh proses control mement yang dilakukan. Pada gambar juga menunjukkan bentuk deformasi pada bagian deck mengalami perubahan bentuk, dimana stiffener dan pelat yang terdapat pada bagian tersebut mengalami tekuk.

\section{Kesimpulan}

Penelitian ini menggunakan metode nonlinear finite element analysis (NLFEA) untuk menginvestigasi kekuatan-batas momen lentur dan tegangan kerja pada box girder dan kapal tanker. Dari hasil metode NLFEA yang diperoleh dapat disimpulkan bahwa kekuatan-batas momen lentur untuk box girder sebesar 6,311 x $10^{8} \mathrm{Nmm}$ kondisi hogging dan $-6.311 \times 10^{8} \mathrm{Nmm}$ kondisi sagging. Sedangkan kekuatan batas kapal tanker dengan besar momen lentur 10,2 x $10^{12} \mathrm{Nmm}$ telah mencapai momen ultimate pada kondisi hogging dan $-8,98 \times 10^{12} \mathrm{Nmm}$ telah mencapai momen ultimate pada kondisi sagging yang membuat struktur mengalami buckling.

Hasil ini memberikan gambaran hubungan antara kekuatan batas dan curvature serta kekuatan batas dan displacement. Grafik yang muncul menunjukkan batas daerah plastis dan elastis sehingga dapat mengetahui batas keamanan material struktur tersebut.

\section{Referensi}

[1] Djaya,Indra Kusna, 2008, Teknik konstruksi kapal, Departemen Pendidikan Nasional, Jakarta.

[2] DNV GL. 2017a. Rules for Classification: Ships, Pt.3 Ch.4. Loads. Norway.

[3] Gere, James M. 2004. Mechanics of Materials, Edisi keenam. Thomson Learning, Inc. USA.

[4] Biro Klasifikasi Indonesia (BKI). 2017. Volume II. Part 5. Seagoing Ships. Schodek L. D. 1998. Struktur. PT Rafika Aditama. Bandung.

[5] Muis Alie, M. Z. et al. 2012. Residual Longitudinal Strength Analysis of Ship's Hull Girder with Damages. Proceedings 22nd International Offshore and Polar Engineering Conference, ISOPE, Rhodes, Greece, Vol 4: 831-838.

[6] Y Bai, E Bendiksen, P Terndrup Pedersen. 1993. Collapse Analysis of Ship Hulls.Departement of ocean Engineering, The Technical University of Denmark. 